\title{
小児䐅頭異物 症
}

\author{
戸田 行雄・大高詳一郎・中島 久美 \\ 岩沢寛・竹山勇
}

\section{Laryngeal Foreign Body in Infant: A Case Report}

\author{
Yukio Toda, Shoichiro Ootaka, Kumi Nakajima, \\ Hiroshi Iwasawa and Isamu Takeyama
}

(St. Marianna University)

Recently we treated a 15-month-old female with a plastic toy fixed in the glottis.

In the past 25 years, 14 infants with laryngeal obstruction by a foreign body have been reported in Japan. The type and site of obstruction of the foreign bodies and the duration of their enlodgement were investigated.

In 12 of the 14 patients, the foreign bodies were some form of food, and in 13, the foreign body was radiolucent. In half of the patients, the foreign body had been present for more than a month.

Among the many examinations used, auscultation and soft lateral roentgenograms of the neck seemed to be the most useful in the diagnosis of this condition.

Laryngeal foreign bodies accounted for $0-4 \%$ of the total number of foreign bodies in the respiratory tract. In cooperation with pediatricians and radiologists, otolaryngologists can improve the accuracy of diagnosing this disease.

Otolaryngologists should always suspect foreign bodies and perform direct laryngoscopy when children with stridor are examined.

Key words : larynx, foreign body, infant, case report

緒 言

小児気道異物中に喉頭異物の占める割合は比較的稀である亡考えられるが，堠頭の異物症はその 症状が急性炎症に類似し，一方小児では，十分な問㟝がえられず，また閒接喉頭鏡やファイバース コープでの観察が極めて困難であり, さらに異物がX線透過性のものが極めて多いと考えられるた め, その診断には難渋することが多い。最近, 私共は, 小児喉頭異物症例を取扱い, 積極的に喉頭 直達鏡検查の必要なことを経験した。本症例の経過と診断上の反省点および小児喉頭異物症につい ての文献的考察を述べる.

症

例

1) 経 過

現病歴：昭和59年 7 月 23 日，子供同志で遊ん

症例：1才 3 力月, 女児

でいる時, 突然, 峐き込み口唇のチアノ一ゼが

聖マリアンナ医科大学耳鼻咽喉科学教室 
出現したため, 母親が子供を逆さまにして背中 をたたいたところ，ポテトチップを吐き，チア ノ一ゼは消失した。しかし，その後む軽度の喘 鳴が聞かれたため翌日近医を受診し，感冒のた めであろうと言われ内服を処方され, 一時, 症 状が坚快した。しかし，8月21日頃より喘鳴が 増強し, 陷凹呼吸が出現したため某病院耳鼻科 在経て救急車にて当院耳鼻科に来院した.

初診時所見：チアノーゼはなかったが陥凹呼 吸がみられ, 胸部聴診では喘鳴が著明であった が, 左右差はみられなかった。胸部X-P所見で は異物除影はなく, Holzknecht sign あ認め られなかった。また頸部軟部撮影でも異物陰影 はみとめられず，正面像では声門下には異常所 見がみられなかった (写真 1 ). 母親の話しで はポテトチップ以外に異物䛊飲の心当りはない ということであったが, 積極的に異物の存在を 否定する所見が得られなかったため全麻下にて 異物の有無を点検することにした，術前の白血 球数は $13,000 / \mathrm{mm}^{3}$ であった。

手術時所見：マスクにより，フローセン麻酔 を行い，小児用喉頭直澾鏡を介してベンチレー ションブロンコスコピーに移ろうとしたが, 声 門に肉芽と共に異物の一部がみられたため鈷子 にて除去した（写真 2$)$. その後ベンチレーシ ヨンブロンコスコピーにて下気道に異物のない ことを確認した。声門には肉芽が認められた が, ベンチレーションブロンスコープおよびマ イクロリンゴサージェリーのための気管内チュ 一ブ择入操作により大部分の肉芽は消失し,さ らに残りを鈿子にて除去して手術を終了した。

術後, 喘鳴, 陷凹呼吸は消失し 5 日後に退院し た. 後日, 頸部軟部撮影側面像を再点検すると 肉芽のためと思われる軟部組織腫脹の陰影がみ られた (写真 3 ).

\section{2) 症例に関する考察}

本例では 1 才 3 カ月という年秢のため, 声門 が小さく $12 \times 8 \mathrm{~mm}$ 玩具が声門を通過できずに 声門に陷頓したと思われるが，一度気管に入っ たものが咳嗽によって再び声門に陷頓したとも

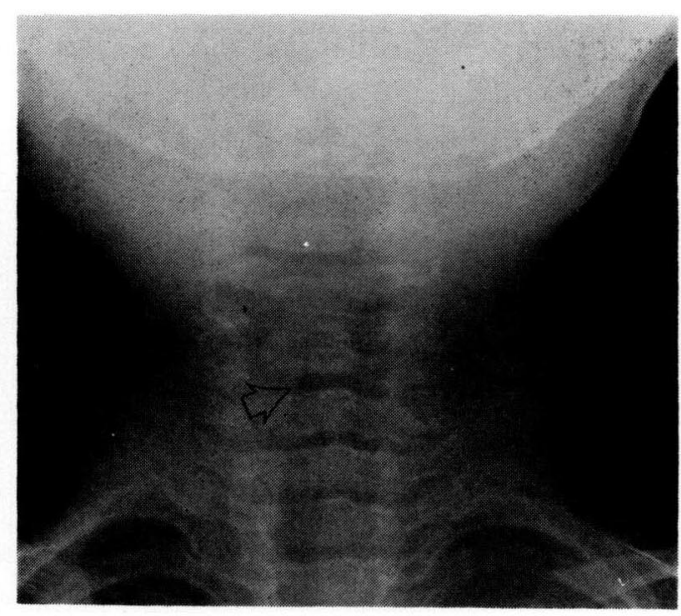

写真 I 頸部軟部撮影正面像 声門下には異常はみられなかった（知印）

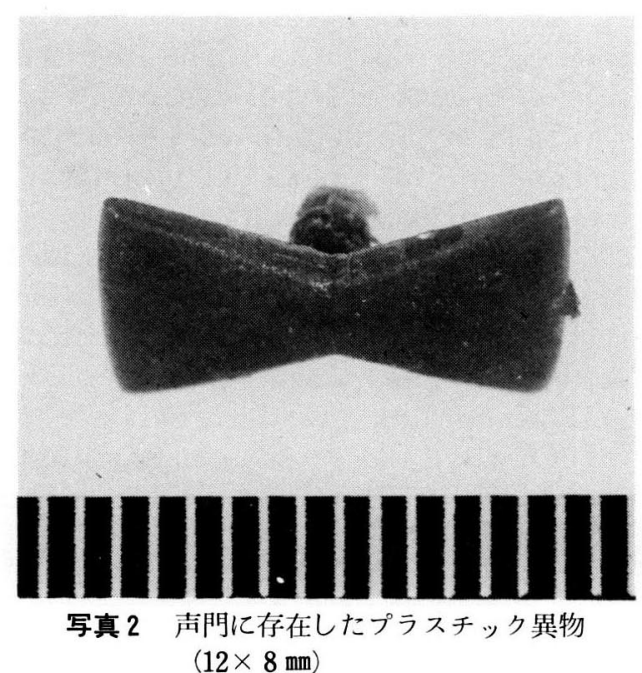

考えられる.いずれにせよ，異物が気道を完全 に閉塞しないという形態的特徴や素材がプラス チック製であったため周囲組織に与える刺激が 少く，また，治療として投与されていた抗生物 質のためむあって, 異物周囲の気道における肉 芽の発生が遅れ, 気道が部分的に確保され症状 が比較的軽かったので上気道炎として治療され ていたもの上考えられる. 母親が異物の吸入を 否定したことや聴診所見および X-P 所見が気 管支異物として説明できない所見であったこと など, 異物の存在が考え難い一方, 声門あたり 


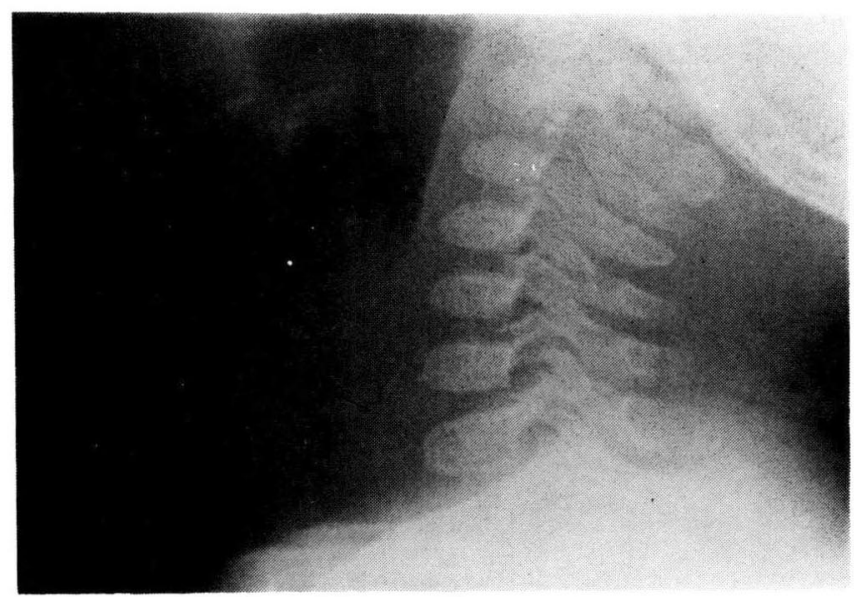

写真 3 頸郎軟部撮影側面像

矢印は考門に一致した気道の狭小を示す。

の喘鳴が一番大きいにもかかわらず頸部軟部撮 影正面像で声門下に異常がないことなど症状を 説明できない所見むあり, 異物の存在の有無を 点検する目的で手術を行い，声門に介在したプ ラスチック製玩具を摘出したものである．私達

考

\section{1 ）小児喉頭異物の頻度}

最近の国内外における気道異物中に占める喉 頭異物の割合についての主な調査は以下のごと くであり（表1），1976年 $\mathrm{Aytac}^{2) （ ト ル コ ） ~}$ 464例中 0，1977年 Daniilidis ${ }^{9}$ （ギリシャ） 90
が本患者の診断をするにあたり，反省すべき点 が多かったので特に小児喉頭異物症の診断をす るにあたって注意をすべき事項について考察し てみたい.

\section{察}

例中 11 例, 1979 年 西條 $^{30)}$ (日本) 55 例中 0 , 1980年 Blazer ${ }^{3)}$ (イスラエル) 200例中 8 例, 1980年 Rothmann ${ }^{29)}$ (アメリカ) 225例中 5 例, 1980年 Cohen $^{8)}$ (アメリカ) 143例中 6 例, 1981 年 大戸 ${ }^{26)} 28$ 例中 0,1983 年 仁瓶 ${ }^{21)} 28$ 例中 0 な

表 | 小児喉頭異物症の頻度

\begin{tabular}{|c|c|c|c|c|}
\hline & 報 告 者（国 名） & 調査期間 & 喉頭異物症／気道異物症の比率 & 備 考 \\
\hline 1 & 1976, Aytac (トルコ) & $?$ & $0: 464$ & 小児つみ \\
\hline 2 & 1977, Daniilidis（ギリシャ） & 6 年間 & 1190 & \\
\hline 3 & 1979, 西㳵（日本） & 6 年間 & $0 / 59$ & \\
\hline 4 & 1980, Cohen (米) & 5 年間 & 6.143 & 小児のみ \\
\hline 5 & 1980, Rothmann (米) & 25年間 & 5225 & \\
\hline 6 & 1980, Blazer (イスラェル) & 12年間 & 8,200 & 小児のみ \\
\hline 7 & 1981, 大戸 (日本) & 10年間 & $0 / 28$ & \\
\hline 8 & 1983, 仁瓶（日本） & 10年間 & $0 / 28$ & \\
\hline
\end{tabular}


どである．特に $\mathrm{Cohen}^{8)}$ の調査は小児のみに対 する気道異物の統計であり， 5 年間 143 例の気 道異物中， 6 例の喉頭異物を数えたとあり，小 児喉頭異物の頻度を知る上で貴重なものであ る. 同様に Blazer ${ }^{3)}$ の報告は 12 年間200例の小 児のうち 8 例に認めている。 また, $\mathrm{Aytac}^{2)} の$ 464 例むす心゙て小児に関するものであり喉頭異 物を 1 例もみていない，従って気道異物症のう ち小児喉頭異物症が占める割合はおよそ $0 \sim 4$ \%程度であると考えられる．また，㬋頭異物が どの部位に存在していたかは諸家の報告にあ述 べられておらず，ただ森本 ${ }^{19)}$ (1953年) が声門 下腔に最屯多く $50 \%$ を上わり，声帯間に最も 少く約 $5 \%$ に過ぎないと報告し, 他に上田 ${ }^{36)}$ （1964年）は 7 年間の喉頭異物の内訳を声門間 隙 3 例, 声門下腔 1 例, 梨状陥凹 3 例之報告し ている. そこで，過去 25 年間の本邦における小 児喉頭異物報告例のうち記載の明瞭なもの之自 験例を含めて14例を整理すると，部位別の内訳 としては, 声門 8 例, 声門上 1 例, 声門下 5 例 であった。いずれにせよ喉頭異物の存在はその 数が少いので, 多くの症例が集積されないと異 物存在の部位についての詳細は不明である.

2 ) 小览喉頭異物の種類
倠頭異物一般については, 後藤 ${ }^{11)}$ （1960年）, 粟田口 ${ }^{1)}$ (1970年) によれば，魚骨が多いとと が，また，笹木 ${ }^{32)}$ (1954年），上田 ${ }^{3)}$ (1964年） あ声带間異物として魚骨が多いととを報告して いる.

本邦25年間の小児喉頭異物のうち異物の種類 は 14 例中 12 例が食物およびそれに関するもの であり，僅かに 2 例のみが食物之無関係であっ た. また，素材としては，ステープルの例を除 いたすべてが radiolucent なむのであると考え られ，X線学的診断の難かしいことを同わせ, このことは, 異物の留置期間が14例中半数にお いて1 カ月以上に及んでいることによっても裹 付けられる（表 2 ).

3 ）国外における喉頭異物について

国外における喉頭異物に関する主な記載は表 3 のごとくであり，食物に関するものは，とう あろこし, 豆, 果物, 卵の殼などであり, 食物 に関係ないあのとしては，プラスチック製笛，

鋲, 金属製笛, フィルムの切れ端, スプリング などである（表 3 ）。国外における食物に関す るものとしては国内に拉ける魚骨や力二, エビ の殼などが多いのと異なり, 両者での食生活の 相違によるものと考えられた。

表 2 本邦過去25年間の小児喉頭異物症報告例

\begin{tabular}{|c|c|c|c|c|c|c|c|}
\hline & 報 & 告 者 & 年 令 & 性別 & 異 物 の 種 類 & 存在部位 & 留置期間 \\
\hline 1 & 広戸 & （1959年） & 1 才 7 ケ月 & 男 & 魚 & 声門 & 50 日 \\
\hline 2 & 平野 & （1960年） & 2 才 9 ケ月 & 男 & $ア メ 玉$ & 声門上 & 当日 \\
\hline 3 & 瀬戸 & （1960年） & 1 才 3 ケ月 & 女 & エビフライのしっぽ & 声門下 & 45日 \\
\hline 4 & 市原 & （1961年） & 2 才 & 男 & アサリの破片 & 声門 & 当日 \\
\hline 5 & 上田 & (1964年) & 4 才 & 女 & 殼 & 声門 & 当日 \\
\hline 6 & 古川 & （1974年） & $1 才$ & 女 & 骨 & 声門 & 6 日 \\
\hline 7 & 渡辺 & （1976年） & 1才 7 ケ月 & 男 & タマゴパックのプラスチック & 声門下 & 70日 \\
\hline 8 & 大野 & （1977年） & $1 才$ & 女 & 魚 の 鰓 & 声門 & 40日 \\
\hline 9 & 岡本 & （1978年） & $6 才$ & 男 & 力 $=$ の 足 & 声門下 & 180日 \\
\hline 10 & 斉藤 & （1980年） & 1才 4 ケ月 & 男 & 魚 & 声門 & 当日 \\
\hline 11 & 平林 & (1980年) & 1 才 3 ケ月 & 男 & チョコレートのアルミ箔 & 声門下 & 3 日 \\
\hline 12 & 村上 & （1982年） & 1才 8 ケ月 & 男 & ステープル & 声門 & 21日 \\
\hline 13 & 吉田 & （1982年） & 4 才 & 女 & 魚 & 声門下 & 43日 \\
\hline 14 & 戸田 & （1984年） & $1 才 3$ ケ月 & 女 & プラスチックのおもちゃ & 声門 & 30 日 \\
\hline
\end{tabular}


表 3 国外過去 20 年間の小児喉頭異物症の主 な報告例

\begin{tabular}{|c|c|c|c|c|c|}
\hline & 報告者（国名） & 症例年令 & |性| & 重類 & \begin{tabular}{|l|}
$\mid$ 異物の \\
部位.
\end{tabular} \\
\hline 1 & $\begin{array}{l}\text { Boddam- } \\
\text { whatharm } \\
1983 \text {, イギリス }\end{array}$ & $\begin{array}{l}5 才 \\
5 \text { 才 }\end{array}$ & 畕 & とうも豆こし & \\
\hline 2 & $\begin{array}{l}\text { Malik } \\
\text { 1982, インド }\end{array}$ & 8才 & 男 & $\begin{array}{l}\text { プラスチック製 } \\
\text { おもちゃの笛 }\end{array}$ & 声門 \\
\hline 3 & $\begin{array}{l}\text { Roberts } \\
\text { 1982, アメリカ }\end{array}$ & 5 才 & 男 & 鋲 & 声門 \\
\hline 4 & $\begin{array}{l}\text { Panna } \\
\text { 1981, インド }\end{array}$ & ケ月 & 女 & スケット & \\
\hline 5 & $\begin{array}{l}\text { Chaturvedi } \\
\text { 1981, インド }\end{array}$ & 9才 & 男 & 金属製笛 & \\
\hline 6 & $\begin{array}{l}\text { Soni } \\
\text { 1979, インド }\end{array}$ & 6ケ月 & 男 & 果 物 & \\
\hline 7 & $\begin{array}{l}\text { Morioka } \\
1975 \text {, アメリカ }\end{array}$ & 11ケ月 & 女 & フィルム & 閒 \\
\hline 8 & $\begin{array}{l}\text { Pollard } \\
1970 \text {, イギリス }\end{array}$ & 1才6ケ月 & 女 & 卵 殼 & 声門 \\
\hline 9 & $\begin{array}{l}\text { Chhangani } \\
\text { 1966, インド }\end{array}$ & 12才 & 男 & スプリング & 声門 \\
\hline \multirow[t]{8}{*}{10} & $\begin{array}{l}\text { Weston } \\
1965 \text {, アメリカ }\end{array}$ & (1) 6 ケ月 & 女子 & $\begin{array}{r}\text { プラスチック製 } \\
\text { びんのふた }\end{array}$ & \\
\hline & & & & $\begin{array}{r}\text { プラスチック製 } \\
\text { ボタシ }\end{array}$ & 声門上 \\
\hline & & (3) 1 才 & 女 & 金属製ネジ & 声門上 \\
\hline & & (4) 1 才 & 女 & コーン & 声門 \\
\hline & & (5) 2才 & 男 & フランクフルト & 声門上 \\
\hline & & (6) 4 才 & 女 & サラミ & 声門 \\
\hline & & (7) 7 才 & 女 & キャンディー & 声門 \\
\hline & & (9)13才 & 女 & 乾燥鼻漏 & 声門 \\
\hline
\end{tabular}

4 ）小児喉頭異物の死亡報告例

不幸な転帰をとった小児喉頭異物症例につい てはほとんど報告をみないが，Weston ${ }^{3)}$ (1965 年, アメリカ），立有 ${ }^{36)}$ (1977 年, 日本)，

Boddam $^{4)}$ (1983 年, イギリス) などの報告が 僅汃にられ, 本症の診断, 治療を考えるのに 貴重な資料である（表 4 ），それによると，食 物に関するあのとそれ以外のものが半数ずつを 数え, 部位としては声門上のむのがやや多い. また，ほとんどの症例が病院到着前あるいは到 着直後に死亡しており, 救急処置の必要性を考 えさせる。

\section{5 ）小览喉頭異物の診断}

Davision $^{10)}$ (1968年)によれば，小児のacute laryngeal obstruction の原因は， 1. acute
表 4 小児喉頭異物症による死亡報告例

\begin{tabular}{|c|c|c|c|c|c|}
\hline & 報告者（国名） & 年令 & |性| & 異物の種類 & $\begin{array}{l}\text { 異物の } \\
\text { 部位 }\end{array}$ \\
\hline 1 & $\begin{array}{l}\text { Boddam- } \\
\text { whetharm } \\
1983, イ キ ゙ リ ス\end{array}$ & 5 才 & 男 & とうもろこ & 下 \\
\hline 2 & $\begin{array}{l}\frac{\text { 立木 }}{1977, \text { 日本 }} \\
\end{array}$ & 5 ケ月 & $?$ & 玩 具 & 喉頭部 \\
\hline 3 & $\begin{array}{l}\text { Weston } \\
1965 \text {, アメリカ }\end{array}$ & (1) 6 ケ月 & 女 & $\begin{array}{r}\text { プラスチック製 } \\
\text { びんのふた }\end{array}$ & 声 \\
\hline & & (2)11 & 男 & プラスチック製 & 声門上 \\
\hline & & (3) 1 才 & 女 & 金属製ネジ & 声門上 \\
\hline & & (4) 1才 & 女 & コーン & 声門 \\
\hline & & (5) 2才 & 男 & フランクフルト & 声門上 \\
\hline & & (6) 4 才 & 女 & サラ & 声門 \\
\hline & & (7) 7 才 & 女 & キャンディー & 声門 \\
\hline & & (9)13才 & 女 & 乾燥鼻漏 & 声門 \\
\hline
\end{tabular}

epiglottits 2. Supra glottic allergic reaction 3. laryngeal diphtheria 4. subglottic allergic edema (spasmodic croup, false croup) 5. acute laryngo-tracheo-branchitis 6 . foreign body in the larynx or upper trachea であるとされ，まず常に異物の存在を 念頭において診断をすすめることが大切であ る。また，Morioka ${ }^{20)}$ （1975年）は，小児の気 道異物の診断治療が遅れるのは，1）小児では 十分な問診が得られない，2）親が異物の誤飲 を知らないことがある．3）親は咳嗽中に異物 が排出されたと信じているととがある，4） sign や symptom が誤解されていることがあ る. 5 ）異物が X-P に写らないなどを挙げて いる．私達が診断の途中で問題になこたことが 見事に列記されている，最近ますます radiolucentな素材が日常生活において普及してきてい ることより，むしろ，今後， X-P にて直接異 物がみつけられることは, 極めて稀であると考 えなくてはならない，従って吸気と呼気の胸部 $\mathrm{X}$ 線, そして頸部軟部撮影の正面, 側面は最小 限必要な X線検査であると考えられる。候頭の 解剖学的特徵によれば, cricoid ring が最も狭 い部位であるため異物はこの部位の特殊性によ って,その向き方が規定され,一般的には sagit- 
tal plane になると考えられるため頸部軟部撮 影側面像によって異物周囲の肉芽の有無等を重 点的に調査するととが大切と思われる. 私達の 症例でも, 術後, 頸部軟部撮影側面像を再点検 したところ，声門に一致して肉芽によると思わ れる軟部陰影を認めている(写真 3 )。なお小児 においては laryngeal cartilageのcalcification はまだ未完成であるので魚骨異物の診断におい て䛊ることはない(40) と思われる，その他のX線 学的搒断法として断層撮影, CT, Xerography, 肺シンチなどがあるが，断層やCTは小児にと っては，体動があるためになかなか利用しにく く, 肺シンチは喉頭異物では無効という報告が ある ${ }^{13)}$. 今後, ビデオなどによるスローモーシ ョン画像による診断む有効と考えられる，その 他の診断法として primitive ではあるが聴診が 最も大切と思われ, 小児科医の聴診の優劣によ り，気道異物の診断の技術は規定されるともい われているが, 喉頭異物症の場合でもあてはま
ると思われ，特に小児においては，小児科医， 放射線科医と耳鼻科医とが密接に連絡をとり， 診断精度をあげることが大切と思われ，また， 異物の存在が否定できない場合には積極的に直 接喉頭鏡検査を行うことが重要である.

6 ）小児喉頭異物の救急処㯰

瀧野 ${ }^{35)}$ は, 異物䛊臙と同時に呼吸困難, 窒息 を来す喉頭入口部の閉寒の場合上, 最初に激し く陔込み, 呼吸困難となり苦しみ, チアノ一ゼ を呈する気管異物の場合とを鑑別し，それぞれ に適応した救急処置を行うことが必要である が，両者の鑑別むしないで救急処置を行ってい る傾向があると述べている。また，日野原 ${ }^{12)}$ は， ハイムリッ七法の啓蒙が大切なととを述べてい るが, 前述した死亡例では病院到着前あるいは 直後の死亡例が多く，ハイムリッヒ法により救 命された可能性が高く，今後とも救急処置の重 要性を啓蒙してゆくことが大切と考えられる.

\section{ま と め}

1. 喘鳴を主訴として来院した 1 才 3 力月女児 においてプラスチック製玩具を喉頭より除去 した.

2. 本邦過去 25 年間の小览喉頭異物症例を整理 すると，その種類は14例中，12例が食物に関 するものであり，1例を除いてすべてが radiolucent なものであり，またその半数にお いてその留置期間が 1 力月に及んでいた。

3. 国外における気道異物症のうち小児喉頭異

結
物症の占める割合は $0 \sim 4 \%$ 程度であった。

4. 小巟喉頭異物症の診断には聴診および頸部 軟部撮影側面像による検査が有用であると思 われた。

5. 小児の喘鳴患者を診察するにあたっては常 に異物の存在を念頭において検査をすすめる ことが必要であり，その疑いがあれば，積極 的に直接喉頭鏡検査を行うことが大切である と思われた。

語

1 才 3 カ月女児プラスチック製玩具の喉頭異物症例で，誤燕後 1 力月経過した時点で摘出した小 児喉頭異物症の診断の困難さを経験し，小児喘鳴に遭遇した際には，常に異物症の存在を念願にお き検査をすすめ, 疑わしき時には積極的に直接喉頭鏡検査を行うべきことを強調した。

本論文の要旨は第49回, 日本耳鼻咽喉科学会神奈川県地方部会において発表した. 


\section{参考文 献}

1) 粟田口省吾, 他：診療科として気管食道科はいか にあるべきか，気管食道鏡検査症例の推移から。 気食 $21 ： 96 \sim 102 ， 1970$.

2 ) Aytac A, et al: Inhalation of foreign bodies in children. J Thorac Cardiovasc Surg 74 : 145 151, 1977.

3 ) Blazer S, et al : Foreign body in the airway. Am J Dis Child 134:68 71, 1980.

4) Boddam-whecham $\mathrm{AH}$ : The choking child. Br Med J 286:980, 1983.

5) Chaturvedi VN : "whistling sign"_ A diagnostic feature of laryngo-tracheal foreign body. Indian Pediatr 18:752 754, 1981.

6) Chhangani DL, et al: An unusual foreign body in the larynx. J Laryng $80: 974 \sim 976$, 1966.

7) Choudhury $P$ : An unusual foreign body in the subglottic region. Indian Pediatr 18:269, 1981.

8) Cohen SR, et al : Foreign bodies in the airway. Ann Otol 89:437 442, 1980.

9) Daniilidis J, et al : Foreign body in the airways. Arch Otolaryngol $103: 570 \sim 573,1977$.

10) Davision FW : Acute laryngotracheal infections in childhood. Otolaryngol Clin North Am, W.B. Saunders, Philadelphia, 1968.

11) 後藤敏郎: 耳鼻咽喉科学. 医学書院, 東京, 1960.

12）日野原正：救急のコッ・気道異物. 臨床と研究 $57: 1562 \sim 1565,1980$.

13）平林秀樹, 他 : 比較的珍しい気管・気管支異物 5 症例. 気食 $31: 438 \sim 443,1980$.

14）平野一弥，他：興味ある声带間異物の 1 症例. 耳 搌 $32: 79 \sim 80,1960$.

15）広戸幾一郎：長期嵌留により乳嘴腫を発生したと 思われる喉頭異物の 1 例. 耳鼻臨床 $52 ： 964$ 967, 1959.

16）古川 満, 他：稀有な声帯間異物（あじの“ぜん ご”)の一症例. 耳鼻 $20: 421 \sim 423 ， 1974$.

17）市原正雄：興味のあった咽喉頭異物症. 昭和医学 会雑誌 $21 ： 798 \sim 800,1961$.

18) Malik MK: Rare laryngeal foreign body in a child. Indian Pediatr 19:95 96, 1982.
19）森本正紀, 他：長期滞留の声帯間ならびに食道入 口部異物の各 1 例. 気食 $4: 122 \sim 125,1953$.

20) Morioka WT: Unexpected radiographic findings related to foreign bodies. Ann Otol $84: 627 \sim 630,1975$.

21）仁瓶誠五，他：当院における気管・気管支異物 10 年の統計的観察之興味ある若干例について.耳鼾 臨床 $76: 753 \sim 763,1983$.

22）村上正文, 他：声門に嵌入したステープル異物症 例. 気食 $33: 233 \sim 236,1982$.

23）岡本亮二, 他：Pyogenic Granuloma を主病変と した小児喉頭室異物症例. 気食 $29: 378 \sim 382$, 1978.

24）大野政一, 他：興味ある小児喘鳴の 3 症例につい て. 気食 $28: 269 \sim 273 ， 1977$.

25）大野政一, 他 : 気道異物症の小験とその問題点に ついて. 耳鼻 $24: 433 \sim 438,1978$.

26）大戸武久, 他：当教室 10 年間の気道および食道異 物の臨床統計的観察. 気食 $32: 241 \sim 248,1981$.

27) Pollard JA : Clinical records. Long-standing laryngeal foreign body. J Laryng $84: 323 \sim$ $325,1970$.

28) Roberts LS : A unique method for the anesthetic management of laryngeal foreign bodies. Anesthesiology $56: 480 \sim 482,1982$.

29) Rothmann BF : Foreign bodies in the larynx and tracheo-bronchial tree in children. Ann Otol $89: 434 \sim 436,1980$.

30）西條 茂, 他: 気道異物症例の統計的観察. 耳鼻 $25: 319 \sim 322,1979$.

31）斉藤久樹, 他：気道内魚骨異物. 気食 $31: 431 \sim$ 437,1980 .

32）笹木 実: 日本耳鼻咽喉科全書. 日本医書出版, 3 巻 4 冊, 207 234, 1954.

33）瀨戸黄夫：声門下腔異物の一例. 耳鼻 $6 ： 208$ 209, 1960 .

34) Soni NK: A vegetative foreign body of the subglottic region. Indian Pediatr 16:553 $554,1979$.

35）瀧野賢一：気道異物, 最近の傾向について. 気食 $28: 179 \sim 183.1977$.

36）立木 孝：異物致死例・ その対策. 気食：24 
$221,1973$.

37）上田直昭, 他：興味ある喉頭異物卵㲄 1 症例. 気 食 $15: 249 \sim 252,1964$.

38）渡辺庄次，他：乳幼児における下咽頭・気管内異 物の 2 症例. 日農医誌 $25: 222 \sim 223,1976$.

39) Weston JT : Airway foreign body fatalities in children. Ann Otol 74:1144 1148, 1965.

40) Withers TB : Foreign bodies of the larynx.
Ann Otol $58:$ 1085 1092, 1949.

41）吉田重彦，他：幼児の声門下魚骨異物の 1 症例. 耳喉 $54: 45 \sim 48,1982$.

原稿到着：昭和 60 年 3 月 8 日 別刷請求先 : 戸田行雄

T213 神奈川県川崎市宮前区营生2095 聖マリアンナ医科大学耳鼻咽喉科学教室 